\title{
Leading for Diversity: How Islamic School Leaders View Diversity
}

\author{
Agus Mutohar \\ Universitas Islam Negeri Walisongo Semarang, Indonesia
}

\{agusmutohar@walisongo.ac.id\}

\begin{abstract}
Indonesian Islamic schools known as madrasah have drawn attention worldwide due to terrorists' affiliation with some Islamic schools in Indonesia. This study is aimed at understanding three focuses namely the definition of diversity, the benefit of diversity, and the issues of diversity in the eyes of Islamic school leaders. Diversity is a much-needed concept and program at schools amidst growing ethnic, religious, and cultural interactions among countries around the world. Today's schools consist of teachers, administrators, students with diverse socio-cultural backgrounds. School leaders need to manage these differences into advantage factors for school performances.
\end{abstract}

Keywords: Islamic School Leaders; Diversity

\section{Introduction}

Indonesian Islamic schools known as madrasah have drawn attention worldwide due to terrorists' affiliation with some Islamic schools in Indonesia. Bergen \& Pandey [1] and Hasan [2] indicate that such hardliner groups are splinters movement separated from the major Islamic school system. Literature also points to the fact that the majority of Islamic schools remain to teach moderate Islam [3]. The purpose of this research was to explore how and in what ways Islamic school leaders in Indonesia view diversity. The concept of diversity is a wide and multifaceted term. The diversity concept used in this paper is synonymous with the ways in which school leaders view diverse religious expressions both within and outside Islam. The diversity concept can be seen as a process of acknowledging various backgrounds such as gender, language, religion, group, and political choice as a consideration when deciding school policies [4]. Diversity is a much-needed concept and program at schools amidst growing ethnic, religious, and cultural interactions among countries around the world. Today's schools consist of teachers, administrators, students with diverse socio-cultural backgrounds. School leaders need to manage these differences into advantage factors for school performances.

The centrality of a positive attitude toward diversity in schools lies behind progressive school leaders. School leaders have a pivotal role in relation to diversity because of their formal role in schools to create schools' programs that nurture inclusion toward diversity. Research shows that leadership influences the education students to receive and that principals have the agency to leverage positive change in schools including advocating for positive views toward diversity [5], [6]. The perspective adopted in this study is to examine the interplay of 
leadership and diversity in private Islamic schools in Indonesia. This paper, however, does not attempt to study all the various characteristics of Islamic schools in Indonesia. The study recognizes that there are areas within private Islamic schools where specific characteristics such as leadership governance could be different and more complex due to the influence of foundation.

\section{Islamic Schools in Indonesia}

According to the Ministry of Religious Affairs (MORA), there are 82.418 Islamic schools from Islamic Kindergartens (Raudhatul Athfal), Islamic elementary schools (Madrasah al Ibtidaiyyah), Islamic middle schools (Madrasah al Tsanawiyyah), and Islamic high schools (Madrasah Aliyah). More than $85 \%$ from the total of Islamic schools in Indonesia are private Islamic schools. In much of the nation today, most of private Islamic schools are managed by two largest Islamic organizations in Indonesia i.e. Nahdlatul Ulama and Muhammadiyah. More than $65 \%$ (76 millions) of Indonesian Muslims subscribe to these organizations that were founded in 1926 and 1912 [7]

The evolution of Islamic schools in Indonesia was originated from Pesantren, the oldest Islamic educational institution in Indonesia. Pesantren is a residential learning center directed by a Muslim Scholar known as Kyai and attended by young Muslim students wishing to learn Islamic studies. [8] While pesantren was originally organized in an informal way, the modernization of pesantren initiates the establishment of formal education institutions in the early decades of the 20th century. Islamic schools are different from traditional pesantren in a way that Islamic schools or madrasah are categorized as formal educational institutions while pesantrens are classified as informal institutions. In terms of curricula, Islamic schools follow the mandated government curriculum and school-based curriculum [9]. Pesantrens, on the other hand, are entirely managed by the kiyais as the highest figure within the institutions. The adoption of formal Islamic schools or madrasah within Pesantren marks the wave of Islamic education transformation. For example, Tebu Ireng, one of the oldest pesantren in Indonesia, opened Islamic schools in the 1930s.

After the Indonesian independence in 1945, the efforts to enhance the quality of Islamic schools in Indonesia took place through the integration of the Islamic school system with modern national education in the country. Private Islamic schools have incorporated government curriculum consisting of religious subjects such as Islamic jurisprudence and Arabic and non-religious subjects such as English and Mathematics [3]. Below is the curricular arrangement that integrates national and Islamic curricula.

Table 1. Subjects in Islamic Schools

\begin{tabular}{clll}
\hline No & $\begin{array}{c}\text { Madrasah Tsanawiyah } \\
\text { (Grade 7-9) }\end{array}$ & $\begin{array}{c}\text { Madrasah Aliyah Science } \\
\text { Program (Grade 10-12) }\end{array}$ & $\begin{array}{c}\text { Madrasah Aliyah Social } \\
\text { Study Program (Grade 10-12) }\end{array}$ \\
\hline 1 & Al Qur'an \& Hadith & Al Qur'an \& Hadith & Al Qur'an \& Hadith \\
2 & Aqidah Akhlak (Ethics) & Aqidah Akhlak (Ethics) & Aqidah Akhlak (Ethics) \\
3 & Fiqh (Islamic jurisprudence)Fiqh (Islamic jurisprudence) & Fiqh (Islamic jurisprudence) \\
4 & Sejarah Kebudayaan & Sejarah Kebudayaan Islam & Sejarah Kebudayaan Islam \\
& Islam (Islamic history) & (Islamic history) & (Islamic history) \\
5 & Pendidikan & Pendidikan & Pendidikan \\
& Kewarganegaraan (Civic) & Kewarganegaraan (Civic) & Kewarganegaraan (Civic) \\
6 & Bahasa Indonesia & Bahasa Indonesia & Bahasa Indonesia \\
& (Indonesian language) & (Indonesian language) & (Indonesian language) \\
7 & Bahasa Arab (Arabic) & Bahasa Arab (Arabic) & Bahasa Arab (Arabic) \\
\hline
\end{tabular}




\begin{tabular}{clll}
\hline No & $\begin{array}{c}\text { Madrasah Tsanawiyah } \\
\text { (Grade 7-9) }\end{array}$ & $\begin{array}{l}\text { Madrasah Aliyah Science } \\
\text { Program (Grade 10-12) }\end{array}$ & $\begin{array}{l}\text { Madrasah Aliyah Social } \\
\text { Study Program (Grade 10-12) }\end{array}$ \\
\hline 8 & English & English & English \\
9 & Mathematics & Art & Art \\
10 & Science & Sport & Sport \\
11 & Social study & Local content & Local content \\
12 & Art & Mathematics & Geography \\
13 & Sport & Biology & History \\
14 & $\begin{array}{l}\text { Information and } \\
\text { communication technology }\end{array}$ & Physics & Sociology \\
15 & Local content & Chemistry & Economy \\
\hline
\end{tabular}

\section{Methodology}

School leadership deals with not only day-to-day school elements but also the wider context of diversity surrounding students, teachers, administrators, parents, and society. Therefore, the ability of school leaders to accommodate diverse community backgrounds influences learning activities in schools. This small scale study examined school leaders from three Islamic schools. The principal of the first school at the time of this study was Mr. Junaidi, a Javanese Muslim from Nahdlatul Ulama background. He graduated from state Islamic university majoring in Islamic education. The second school leader was Mr. Abdullah who was a teacher at the current school and was nominated by the school foundation to lead the school from 2010. He graduated from a state teacher education university in Semarang and attended Pesantren for four years to learn about Islamic studies. The third school, Mr. Ahmad, was a master's degree graduate from state Islamic university. He was considered a loyal member of the school due to his appointment at the current school from 2000.

Data collection for this study occurred in 2018 through an individual interview, site observation, and document analysis. The interview was conducted with school principals. The site observation was aimed at exploring curricular and non-curricular activities as well as posters related to the research project. In general, the researcher sought to understand the whole picture of school leaders' vision and mission related to school-based practice toward diversity. Triangulation was employed through a holistic approach by using multiple sources of information and repeated forms of data collection (Creswell, 2009). Interviews of this study were conducted through a semi-structured interview method to anticipate emerging issues surrounding the research topic. Questions of the interviews ranged from the vision, and mission of the schools and curricular and non-curricular activities concerning diversity views. This study also collected documents including school profiles, school reports, and newsletters to better understand the implementation of diversity programs in schools.

In terms of the theoretical framework, this study adopts the perspective from Dimmock and Walker [10] stating the necessity of school leaders to recognize various cultural backgrounds emerging from their schools' community. This study in particular identified the way in which school leaders understand diverse school backgrounds in terms of their religious affiliations, ethnicity, and other characteristics. 


\section{Result}

This study sought to answer three reserach questions namely how do Islamic school leaders define diversity, how do Islamic school leaders identify the benefit of diversity, and what are some issues and challenges underlying the diversity in Islamic schools?. This section explores these three research questions.

In terms of the definition of diversity, all three Islamic school leaders defined diversity in a more textbook definition such as the use of Pancasila (five principles) concept as the foundation of diversity in which the country upholds diversity. More specifically, Islamic school principals explore issues related to the ways in which school leaders manage multiple identities in schools. The findings highlighted the efforts of school leaders to develop a mixed identity. For instance, Islamic school leaders developed the Indonesian Muslim identity. They attempted to develop students' identity which adhered to the spirit of Indonesian Islam and compatible with plurality, modernity, and democracy. The school leaders referred to a distinctive development of Islam in Indonesia with a peaceful spread of Islam across the country.

Students need to maintain the image of Indonesia so that the world keeps seeing Indonesia as a peaceful country. We do hope that they do something that is useful and gives an impact on their neighborhood (The third school leader). The findings also highlighted a close association of Islamic school leaders with local identities. Islamic school leaders integrated local identities in school curricula and school activities. The school leaders allowed students to acknowledge local Islamic tradition such as praying at the grave and reciting surah Yasin for a family member who passed away:

When there is a family member of the students who have passed away, we pray together, reciting Yasin in the graveyard, guided by their homeroom teacher. The school neighborhood responded very well. At first, this seemed difficult, but when we got used to doing it, many children recited automatically (The first school leader).

Students and staff of the schools involved in religious activities attached to local traditions to help students internalizing inclusive perspectives of local cultures. The Islamic school leaders clearly stated that part of school visions was to teach students to respect various expressions of Islam in society through encouraging students to be involved in activities led by different Islamic groups. Furthermore, students in Islamic schools were encouraged to learn and understand different traditions in Islam through studying muqaranah al mazahib or comparatives of the school of thoughts to understand the dynamics of Islamic sects consisting of Hanafi, Maliki, Shafi'I, and Hanbali. Such tradition explained the openness of Islamic schools toward various traditions in Islam.

The second reserach questions dealt with the discussion of diversity benefits. Two school leaders identify the benefits of diversity in schools as a way to expose students to multicultural situations as well as a way to improve the schools. Islamic school leaders unpack the focus of Islamic schools to develop commonalities. The Islamic school leaders focused on commonalities through the development of human right and education in schools. The leaders indicated their position to support developments of teaching and school-wide activities related to human rights and social justice. Drawing from the interview data, the school leader expressed their point of views related to human right:

My answer is that we should be fair because the Prophet is just and fair. Muslims who steal should be punished. Non-Muslims who do not violate the law, according to Islamic law, should be freed. We must not defend Islam desperately, it is not allowed. Islam does not teach 
like that. The important thing is justice, togetherness, harmony and the important thing is God (The second school leader).

Both Islamic school leaders articulated their religious position grounded on the importance of an inclusive view toward non-Muslims. It was also evident that the school leaders advocated the inclusive view by creating school posters to advocate human rights principles such as an anti-discrimination poster campaign in schools. The school leaders described that the human right and social justice issues were also covered in Islamic studies teaching and general subjects such as civics. The issues and challenges surrounding the diversity in schools were the potential conflicts between religions and within the same religion. The school leaders also identify the resistance from parents for exposing the students to other groups with different religions.

\section{References}

[1] P. Bergen and S. Pandey, "The madrassa scapegoat," Wash. Q., 2006.

[2] N. Hasan, "The Salafi Movement in Indonesia: Transnational Dynamics and Local Development," Comp. Stud. South Asia, Africa Middle East, 2007.

[3] A. Azra, D. Afrianty, and R. W. Hefner, "Pesantren and madrasa: Muslim schools and national ideals in Indonesia," Sch. Islam Cult. Polit. Mod. Muslim Educ., 2007.

[4] S. Polat and D. Olcum, "Characteristics of diversity leadership according to teachers," Anthropologist, vol. 24, no. 1, pp. 64-74, Apr. 2016.

[5] T. E. Deal and K. D. Peterson, Shaping school culture : the heart of leadership. 1999.

[6] Raihani, "An Indonesian model of successful school leadership," J. Educ. Adm., 2008.

[7] MORA, "Statistik Pendidikan Islam (Islamic Education Statistics)," Jakarta, 2011.

[8] F. Pohl, "Islamic education and civil society: Reflections on the pesantren tradition in contemporary Indonesia," Comparative Education Review, vol. 50, no. 3. The University of Chicago Press, pp. 389-409, 17-Aug-2006.

[9] M. Falikul Isbah, "PESANTREN IN THE CHANGING INDONESIAN CONTEXT: HISTORY AND CURRENT DEVELOPMENTS," Qudus Int. J. Islam. Stud., vol. 8, no. 1, p. 2020, 2020.

[10] C. Dimmock and A. Walker, "Educational leadership: Culture and diversity," 2005. 